\title{
Velar Verbs and Verbal Classes in Catalan*
}

\author{
Joaquim Viaplana \\ Universitat de Barcelona. Departament de Filologia Catalana \\ Gran Via de les Corts Catalanes, 585. 08007 Barcelona (Spain) \\ joaquim.viaplana@ub.edu
}

\begin{abstract}
There is in Catalan a set of verbs, the so-called «velar verbs», whose differential characteristic consists in presenting a velar segment between the root and the inflectional suffixes in certain morphosyntactic contexts. This velar segment has traditionally been considered as being part of the root in the contexts where it occurs, and has been made responsible for the typical allomorphic character of velar verbs. Under the assumption that regular verbs are only one-root verbs, velar verbs have been treated as irregular verbs. Nevertheless, neither the phonic character of the velar segment nor the marginal character of velar verbs is clear. The aim of this paper is to present a different account of velar verbs on the basis of the inflectional morphological character of the velar segment. The work is split into two parts. The first one focuses on standard Catalan, and tries to show that in this variety velar verbs are better treated as regular verbs. The second one focuses on other Catalan varieties, and aims to exhibit the incoherence implied in the traditional treatment of velar verbs in the context of the Catalan language as a whole. The discussion is mainly developed on morphological grounds, halfway between theory and description.
\end{abstract}

Key words: inchoative segment, irregular verbs, lexical entries, regular verbs, velar verbs, verbal classes, verbal subclasses; Catalan.

It is a commonplace in Catalan grammar that regular verbs are formally split into three classes and two subclasses. Those verbs following the inflectional pattern of verbs such as cantar 'to sing' are said to be members of verbal class I (cf. (1a)); those following the inflectional pattern of verbs such as perdre 'to lose' are said to be members of verbal class II (cf. (1b)); those following the inflectional pattern of verbs such as sentir 'to feel' are said to be members of verbal class III, noninchoative (cf. (1d)) and, finally, those following the inflectional pattern of verbs such as servir 'to serve' are said to be members of verbal class III, inchoative (cf. (1e)). Verbs such as servir differ from verbs such as sentir only in one respect. In the for-

* This paper has been supported by the Spanish Ministerio de Educación y Ciencia and the FEDER (research project HUM2004-01504/FILO: «Explotación de un corpus oral dialectal (ECOD)»). It also has been benefited by the Departament d'Universitats, Recerca i Societat, from the Generalitat de Catalunya (2005SGR01046). 
mer the verb forms related to present —indicative, subjunctive and imperativefirst, second and third persons singular and third person plural exhibit an extra affix, missing in the latter, between the root and the rest of the inflectional affixes. The affix —an ancient inchoative, formally an extra inflectional affix - is responsible for the names of the verbal subclasses.

All those verbs whose inflectional patterns depart from those of regular verbs are consequently viewed as irregular. Among these, there is a kind of verbs, that of verbs such as beure 'to drink', whose inflectional pattern follows mostly that of verbs such as perdre - that is to say, that of regular verbs belonging to class II. Their irregularity is closely related to the occurrence of a velar segment that happens to exhibit certain verb forms. This segment appears in the verb forms related to the first person singular present indicative, to subjunctive, to the first person plural imperative and, finally, to participle (cf. (1c)). When this velar segment occurs, it is found in the verb forms between the root and the inflectional affixes. This velar segment has been commonly viewed as the last phonic segment of one of the alternative typical roots of those verbs whose verbs forms - some of them at least - contain this segment. These verbs are known, because of the velar segment, as «velar verbs».

In spite of its persistence in literature, this treatment of velar verbs is anything but sufficient. It has never been clear enough why the velar segment of velar verbs should be considered as a phonic segment whereas the inchoative segment of inchoative verbs is considered as a morphological segment.

Furthermore, the empirical data on which this treatment has been based comes from the standard variety of Catalan. Other varieties have also been occasionally taken into consideration, but too often on the assumptions previously made in relation to the standard variety. Nevertheless, many Catalan varieties show morphological verbal patterns containing the velar segment in forms of verbs such as perdre, sentir, servir and even - marginally - in forms of verbs such as cantar. On the grounds of velar verbs being treated as irregular verbs, and as far as verbs are concerned, the regularity scope of these varieties would become simply reduced or very much reduced, depending on the cases.

Is the velar segment appearing in velar verbs just a phonic segment? Are velar verbs really irregular verbs? If they are not, on which grounds are they not? How would an alternative treatment of the velar segment, and thereby of velar verbs, affect the regular verbal classes in Catalan? The main aim of this paper is to give an answer to these questions.

Some points made in this paper have been separately advanced in previous works. ${ }^{1}$ The novelty now must be mainly sought in their occurrence together - which is supposed to make them stronger-, in the refinement of arguments and also, and particularly, in the support given to the whole position by the dialectal data taken now into account. ${ }^{2}$

1. Cf. Viaplana (1984, 1986, 1996), and Lloret and Viaplana (1998).

2. The dialectal data come from the Corpus Oral Dialectal (COD) of the Universitat de Barcelona. 
This paper will be developed in three stages. The first two are aimed at showing the shortcomings of the conventional assumptions on the nature of the velar segment and the convenience of making new ones. The third one is aimed at pointing out the advantages that the alternative assumptions have on the comprehension of the general behavior of regular Catalan verbs and also on their classification. In the first stage standard Catalan will be the only Catalan variety taken into account (cf. (1)). In the second one other Catalan varieties will be also considered.

As the main subject of the paper is centered on verbal extra segments in velar verbs, there seems to be no point in being strict as far as the phonological transcription of the data is concerned. That being the case, the phonological transcription will be reduced to the relevant part of the data; the rest of it will appear, for simplicity reasons, in orthographic transcription.

(1)

\begin{tabular}{|c|c|c|c|c|c|}
\hline & a. cantar & b. perdre & c. beure & d. sentir & e. servir \\
\hline INFINITIVE & cantar & perdre & beure & sentir & servir \\
\hline GERUND & cantant & perdent & bevent & sentint & servint \\
\hline PARTICIPLE & cantat & perdut & be/g/ut & sentit & servit \\
\hline \multirow[t]{6}{*}{ PRESENT INDICATIVE } & canto & perdo & be/g/ & sento & serv/ćf/o \\
\hline & cantes & perds & beus & sents & serv/ćf/es \\
\hline & canta & perd & beu & sent & serv/ćf/ \\
\hline & cantem & perdem & bevem & sentim & servim \\
\hline & canteu & perdeu & beveu & sentiu & serviu \\
\hline & canten & perden & beuen & senten & serv/ćf/en \\
\hline \multirow[t]{6}{*}{ Past Indicative } & cantava & perdia & bevia & sentia & servia \\
\hline & cantaves & perdies & bevies & senties & servies \\
\hline & cantava & perdia & bevia & sentia & servia \\
\hline & cantàvem & perdíem & bevíem & sentíem & servíem \\
\hline & cantàveu & perdíeu & bevíeu & sentíeu & servíeu \\
\hline & cantaven & perdien & bevien & sentien & servien \\
\hline \multirow[t]{6}{*}{ FUTURE } & cantaré & perdré & beuré & sentiré & serviré \\
\hline & cantaràs & perdràs & beuràs & sentiràs & serviràs \\
\hline & cantarà & perdrà & beurà & sentirà & servirà \\
\hline & cantarem & perdrem & beurem & sentirem & servirem \\
\hline & cantareu & perdreu & beureu & sentireu & servireu \\
\hline & cantaran & perdran & beuran & sentiran & serviran \\
\hline \multirow[t]{6}{*}{ CONDITIONAL } & cantaria & perdria & beuria & sentiria & serviria \\
\hline & cantaries & perdries & beuries & sentiries & serviries \\
\hline & cantaria & perdria & beuria & sentiria & serviria \\
\hline & cantaríem & perdríem & beuríem & sentiríem & serviríem \\
\hline & cantaríeu & perdríeu & beuríeu & sentiríeu & serviríeu \\
\hline & cantarien & perdrien & beurien & sentirien & servirien \\
\hline
\end{tabular}




\begin{tabular}{|c|c|c|c|c|c|}
\hline & a. cantar & b. perdre & c. beure & d. sentir & e. servir \\
\hline \multirow[t]{6}{*}{ Present Subjunctive } & canti & perdi & $\mathrm{be} / \mathrm{g} / \mathrm{i}$ & senti & serv/éf/i \\
\hline & cantis & perdis & $\mathrm{be} / \mathrm{g} / \mathrm{is}$ & sentis & serv/éf/is \\
\hline & canti & perdi & $\mathrm{be} / \mathrm{g} / \mathrm{i}$ & senti & serv/ćf/i \\
\hline & cantem & perdem & $\mathrm{be} / \mathrm{g} / \mathrm{em}$ & sentim & servim \\
\hline & canteu & perdeu & $\mathrm{be} / \mathrm{g} / \mathrm{eu}$ & sentiu & serviu \\
\hline & cantin & perdin & be/g/in & sentin & serv/éf/in \\
\hline \multirow[t]{6}{*}{ Past Subjunctive } & cantés & perdés & be/g/és & sentís & servís \\
\hline & cantessis & perdessis & $\mathrm{be} / \mathrm{g} / \mathrm{essis}$ & sentissis & servissis \\
\hline & cantés & perdés & be/g/és & sentís & servís \\
\hline & cantéssim & perdéssim & be/g/éssim & sentíssim & servíssim \\
\hline & cantéssiu & perdéssiu & be/g/éssiu & sentíssiu & servíssiu \\
\hline & cantessin & perdessin & be/g/éssin & sentissin & servissin \\
\hline \multirow[t]{5}{*}{ IMPERATIVE } & canta & perd & beu & sent & serv/ćf/ \\
\hline & canti & perdi & $\mathrm{be} / \mathrm{g} / \mathrm{i}$ & senti & serv/ćs/i \\
\hline & cantem & perdem & $\mathrm{be} / \mathrm{g} / \mathrm{em}$ & sentim & servim \\
\hline & canteu & perdeu & beveu & sentiu & serviu \\
\hline & cantin & perdin & be/g/in & sentin & serv/ćf/in \\
\hline
\end{tabular}

1.0. The most differential element in velar verbs is the velar segment occurring in some of their verbal forms. It results from this that any question about velar verbs implies a previous question about the nature of the velar segment. It will depend very much on how this segment is treated in a grammar that the conclusions on velar verbs turn out to be of one sort or other.

1.1.0. The conventional account of velar verbs considers the velar segment as the last phonic segment in the root of some of their forms. ${ }^{3}$ In this account the velar verbs forms have alternative roots whose occurrences would depend on the grammatical features involved. One of these roots - the most prominent one- is the velar root. In the particular case of the verb beure the verb forms present three different roots, /bćg/, /bćw/ and /bćb/, the first one being the velar root. In an explicit interpretation of this account, the lexicon would have to contain information about how these roots must be distributed in the paradigm on the basis of the grammatical features involved.

In this context velar verbs are assumed to be irregular verbs, as verbs showing the velar root plus other phonological roots. In this respect they differ from inchoative verbs, which are assumed to be regular verbs. As the extra segment / $/ \mathrm{\varepsilon} /$ occurring in some forms of these verbs is treated as a morphological segment -more precisely, as an extension of the root-, no additional root other than the general one is required.

The main problem with this account of velar verbs lays in the fact that no strong reason is been given to handle the velar segment occurring in velar verb forms dif- 
ferently from the inchoative segment occurring in inchoative verb forms. ${ }^{4}$ In fact, both extra segments occur - in the verbal forms in which they occur- between the root and the inflectional affixes, and their occurrence is clearly related to the presence of certain grammatical features in the structure. From a distributional point of view and from a grammatical point of view, therefore, everything seems to suggest that these segments should be better treated as segments belonging to the same formal class. Consequently, formal reasons must be given for them to be treated otherwise.

1.1.1. An implicit reason for treating the inchoative segment and the velar segment differently can be found in an alternative account of the inchoative segment. The empirical basis of this account is the observational fact that the inchoative segment occurs, in inchoative verb forms, in complementary distribution with thematic vowels. On the basis of this fact, it is assumed that this segment is a typical inflectional segment: a thematic segment. As the velar segment does not fulfil any formal condition to be considered a thematic segment, these two extra segments must be handled as segments belonging to different formal classes.

It may be asked, however, whether the complementary distribution argument is as strong as it seems to be at first glance. It is certainly a consistent fact. But is it also a relevant fact so as to justify that formally similar segments should be treated differently? The answer is that it depends on the nature of the complementary distribution involved. If the complementary distribution involved is structure based, and concerns the same kind of deep slot position, it is a relevant fact; if the complementary distribution is stress based, and concerns the surface accent position, it is not a relevant fact.

In the first case, and in accordance with the aforementioned account, the complementary distribution affects the underlying structure of the verbal forms. It comes out from the coincidence of both, the thematic vowels and the inchoative segment, in the class of structural slot positions conventionally headed as a «theme». Cf. (2).

(2)

\begin{tabular}{|c|c|c|c|c|}
\hline Root & Extension & Theme & Mood/tense & Number/person \\
\hline /sərb & & $\varepsilon \int$ & $\mathrm{u} /$ & \\
\hline /sərb & & $\varepsilon \int$ & & $\mathrm{z} /$ \\
\hline /sərb & & $\varepsilon \int /$ & & \\
\hline /sərb & & 1 & & $\mathrm{~m} /$ \\
\hline /sərb & & 1 í & & $\mathrm{w} /$ \\
\hline /sərb & & $\varepsilon \int$ & & $\mathrm{n} /$ \\
\hline
\end{tabular}

4. Reasons to keep the velar segment as a non-morphological segment can be found in Wheeler (1993), recovered in Pérez Saldanya (1998). All of them are suggestive, but very controversial as well. 
In the second case, the complementary distributions may well be understood as the result of a simple accident, with no real weight on the structure. For it to be justified, it is required to assume that the root of verbal forms may be stressed or unstressed, ${ }^{5}$ whereas inflectional affixes are either stressed or unstressed: thematic vowels and the inchoative segment are stressed and the rest of the inflectional affixes are unstressed. It must also be assumed that all the accents in any verb form are finally deleted except for the last one (cf. (2) and (3)); these last representations include the underlying representation (3a) and the surface representation (3b), in which the referred complementary distribution is clearly shown.

(3)

a.

\begin{tabular}{|l|c|c|c|c|}
\hline Root & Ext. & Theme & Mood/tense & Number/person \\
\hline /sərb & $\varepsilon \iint$ & & $\mathrm{u} /$ & \\
\hline /sərb & $\varepsilon \iint$ & & & $\mathrm{z} /$ \\
\hline /sərb & $\varepsilon \int /$ & & & $\mathrm{m} /$ \\
\hline /sərb & & 1 & & $\mathrm{w} /$ \\
\hline /sərb & & 1 & & $\mathrm{n} /$ \\
\hline /sərb & $\varepsilon \hat{\varepsilon} \int$ & & & \\
\hline
\end{tabular}

b.

\begin{tabular}{|l|c|c|c|c|c|}
\hline Root & Ext. & Theme & Mood/tense & $*$ & Number/person \\
\hline$[\operatorname{sər} \beta$ & $\varepsilon \int$ & & $\mathrm{u}]$ & & \\
\hline$[\operatorname{sər} \beta$ & $\varepsilon \int$ & & & $\partial$ & $\mathrm{s}]$ \\
\hline$[\operatorname{sər} \beta$ & $\left.\varepsilon \int\right]$ & & & & \\
\hline$[\operatorname{sər} \beta$ & & 1 & & & $\mathrm{~m}]$ \\
\hline$[\operatorname{sər} \beta$ & & 1 & & & $\mathrm{w}]$ \\
\hline$[\operatorname{sər} \beta$ & $\varepsilon \int$ & & & $\partial$ & $\mathrm{n}]$ \\
\hline
\end{tabular}

* Epenthetic vowel ${ }^{6}$

1.1.2. It seems, therefore, that the complementary distribution between the inchoative segment and thematic vowels may be formally accounted for in structure-based terms or in stress-based terms. The second possibility, however, has two great advantages. It allows inchoative segments and velar segments to be treated as seg-

5. Cf. Mascaró's destressing rule (Mascaró 1978). In this rule it is assumed that verbal roots are stressed. This assumption, however, would involve the acceptance of phonological roots such as /sórb/, with an unexpected vowel —or an unspecified segment— in stressed syllables. In relation to the unstressed character of these kind of roots, cf. also Bonet and Lloret (1998: 205).

6. On the epenthetic character of these vowels, cf. Viaplana (1986). 
ments of the same formal class, as all suggests that it is convenient to do. And it also allows to justify, on more solid grounds, the inclusion of inchoative verbs such as servir in the same verbal class - the verbal class III- as non-inchoative verbs such as sentir.

If, in fact, the inchoative segment were handled as a thematic segment, there would be no way of gathering in the same formal class both inchoative and velar segments. If, on the contrary, the inchoative segment is handled as a root extension segment, there seems to be no problem for the velar segment to be handled in the same manner. That would amount to include both extra segments in the same formal class of verbal segments: that of the «root extension» or simply that of the «extension». Cf. (4a) and (4b).

(4) a.

\begin{tabular}{|l|c|c|c|c|}
\hline Root & Ext. & Theme & Mood/tense & Number/person \\
\hline /sərb & $\varepsilon \int$ & & $\mathrm{i} /$ & \\
\hline /sərb & $\varepsilon \int$ & & $\mathrm{i}$ & $\mathrm{z} /$ \\
\hline /sərb & $\varepsilon \int$ & & $\mathrm{i} /$ & \\
\hline /sərb & & 1 & & $\mathrm{~m} /$ \\
\hline /sərb & & 1 & & $\mathrm{w} /$ \\
\hline /sərb & $\varepsilon \int$ & & $\mathrm{i}$ & $\mathrm{n} /$ \\
\hline
\end{tabular}

b.

\begin{tabular}{|l|c|c|c|c|}
\hline Root & Ext. & Theme & Mood/tense & Number/person \\
\hline$/ \mathrm{b} \varepsilon \dot{\varepsilon}$ & $\mathrm{g}$ & & $\mathrm{i} /$ & \\
\hline$/ \mathrm{b} \tilde{\varepsilon}$ & $\mathrm{g}$ & & $\mathrm{i}$ & $\mathrm{z} /$ \\
\hline$/ \mathrm{b} \hat{\varepsilon}$ & $\mathrm{g}$ & & $\mathrm{i} /$ & \\
\hline$/ \mathrm{b} \hat{\varepsilon}$ & $\mathrm{g}$ & $\hat{\varepsilon}$ & & $\mathrm{m} /$ \\
\hline$/ \mathrm{b} \hat{\varepsilon}$ & $\mathrm{g}$ & $\hat{\varepsilon}$ & & $\mathrm{w} /$ \\
\hline$/ \mathrm{b} \hat{\varepsilon}$ & $\mathrm{g}$ & & $\mathrm{i}$ & $\mathrm{n} /$ \\
\hline
\end{tabular}

Similarly, different verbs are candidates to be included in the same formal verbal class in so far as their paradigms share mainly the same basic inflectional affixes. In the case of Catalan these affixes are clearly those of «theme», «mood-tense» and «number-person» — those of theme being the most sensible ones as far as formal verbal classes are concerned. If the inchoative segment were handled as a thematic segment, verbs such as sentir and verbs such as servir would not share the same theme affixes - which would unable them to be properly treated as members of the same verbal class. If, on the contrary, the inchoative segment is handled as an extension segment, verbs such as sentir and verbs such as servir can be 
included in the same verbal class, as, in this case, they certainly share all basic inflectional affixes. Cf. (4a) and (5).

\begin{tabular}{|l|c|c|c|c|}
\hline Root & Ext. & Theme & Mood/tense & Number/person \\
\hline /sént & & & $\mathrm{u} /$ & \\
\hline /sént & & & & $\mathrm{z} /$ \\
\hline /sént/ & & & & $\mathrm{m} /$ \\
\hline /sént & & 1 & & $\mathrm{w} /$ \\
\hline /sént & & 1 & & $\mathrm{n} /$ \\
\hline /sént & & & & \\
\hline
\end{tabular}

1.2.0. Once supposed that the velar segment is an extension segment, and therefore an independent morphological segment, there still remains the question whether velar verbs have to be considered as regular verbs or as irregular verbs. If the main reason for them to be considered as irregular verbs were the velar segment, and this segment seems to be of the same nature as the inchoative segment, why should velar verbs be considered as irregular verbs whereas inchoative verbs are considered as regular verbs?

As far as the velar segment is concerned, the best solution would seem to be to treat velar verbs as a regular subclass of verbs of class II, similarly as the inchoative verbs are treated as a regular subclass of verbs of class III. But on what bases is it possible to say that inchoative verbs are regular verbs? Furthermore, dismissed the velar root in benefit of an extension root, the velar verbs still depart from verbs such as perdre in two respects: the requirement of more than one root and the lack of an affix in the verb forms related to the grammatical features «present», «indicative», «first person singular». Can these characteristics be causes of irregularity?

1.2.1. The answer to these questions depends on what is understood when something is considered to be regular. There is the conventional agreement that is regular all that can be predicted by general rules. The concept of prediction is essential in the concept of rule. Everything, and only, that is predictable can be established by rules. The scope of rules is the scope of predictability; the scope of predictability is the scope of rules. Where no prediction is possible, no rule can be set up. All that is not predictable is idiosyncratic, and therefore it has nothing to do with the predictions established by rules. ${ }^{7}$

All those linguistic facts that depart from general rules are irregular facts, or irregularities, and are predicted by exceptional rules. Idiosyncratic facts or peculiarities are neither regular nor irregular, as they are out of the domain of pre- 
dictability. They are collected in the lexicon as characteristics of the lexical entries. Each lexical entry is to be viewed as a set of peculiarities sensible to the different linguistic levels. As far as the morphological level is concerned, each lexical verbal entry must be at least endowed with peculiarities such as the verbal root, the category «verb» and the verbal class.

Idiosyncratic facts are not predictable, but this does not mean that they have nothing to do with rules. Rules, in fact, operate on classes of items. Morphological verbal rules operate on morphological verbal classes. What defines these classes is, precisely, the verbal peculiarities sensible to morphology. These peculiarities can be morphosyntactic or morphological; most of them are positive, some of them are negative - preventing from the application of a rule. The scope of morphological verbal classes varies in relation to the peculiarities that they contain. Some verbal classes are general and some are marginal. Morphological verbal rules that operate on general verbal classes are, in this sense, general verbal rules. Non general morphological verbal rules that operate on marginal verbal classes are exceptional morphological verbal rules. The presence of marginal verbal classes in the lexicon alters the general application of the general verbal rules, and constitutes the base of the exceptionality of these verbal rules. Verbs belonging to general verbal classes may be said to be regular verbs; verbs belonging to marginal verbal classes may be said to be irregular verbs.

\subsubsection{Things being seen like this, the decision on which verbs are regular and} which are not hinges on the previous decision on which verbal classes are general and which are not. The trouble now is where to establish the cut between general and marginal verbal classes. Obviously, there is no problem about recognizing as regular verbs those belonging to a verbal class whose morphologically sensitive characteristics are only the phonological root, R; the category «verb», and the verbal class «I»-i.e. cantar; there is no problem either about recognizing as irregular verbs those belonging to a verbal class whose morphologically sensible characteristics includes diacritics such as «[+stress on the root]/ past, indicative», as in caure 'to fall', seure 'to sit' ${ }^{8}$ In both cases intuitive reasons correlate with statistical reasons: verbs such as cantar and ballar 'to dance' constitute the large majority of Catalan verbs, whereas verbs such as caure and seure are just a few.

The decision becomes harder in the case of those verbal classes whose peculiarities place them half way between clear general classes and clear marginal classes. Assuming the extension root nature of the velar segment — and leaving aside for the time being the number of phonological roots-, this is the case of velar verbs. In terms of the properties sensitive to morphological verbal rules, this verbal class can be defined in terms of the category «verb», verbal class «II» and «velar». May this verbal class be considered a general class? The fact that the class of velar verbs contains about 50 verbs seems to justify treating it as a general ver-

8. Cf. the past indicative forms [kéjə], *[kəíə] (from caure) and [sćjə], *[səíə] (from seure), where the agrammatical forms are the ones expected according to Mascaro's (1978) destressing rule. 
bal class. ${ }^{9}$ But, unfortunately, there is no solid criterion available on the ground of which a decision can be taken. In cases like this, in which everything seems to be left in the grammarian's intuition of the facts, it is convenient to take linguistic congruency into account and to give it a leading role in the decision.

It would be wrong to consider that lexical classes behave in such a way that the increase of the peculiarities sensitive to the morphological verbal rules necessarily implies a decrease of the members of the class. In the case of verbs belonging to class III, for example, and as far as their peculiarities sensitive to the morphological verbal rules are concerned, the lexical entries of verbs such as sentir would only differ from the lexical entries of verbs such as servir in the fact that verbs such as servir contain the peculiarity «inchoative» whereas verbs such as sentir do not. Against any intuition about the way in which formal classes usually work, verbs such as servir outnumber verbs such as sentir forty to one - verbs such as servir amounting to about 800 and verbs such as servir amounting to about $20 .{ }^{10}$

It follows from this fact that either verbs such as servir and verbs such as sentir are considered as constituting two general verbal classes, or, alternatively, verbs such as servir are considered as constituting a general verbal class and verbs such as sentir are considered as constituting a marginal verbal class - the other way round is simply not admissible. If the class of verbs such as sentir, amounting to 20 verbs, may be considered as a general verbal class, it would make no sense considering the class of velar verbs, amounting to 60 , as a marginal verbal class.

As far as the velar segment is concerned, therefore, and on linguistic congruency grounds, it seems reasonable to assume that velar verbs constitute a general verbal class and consequently that they can properly be considered as regular verbs.

1.2.3. It has been said above that verbal lexical entries must be endowed with a phonological peculiarity with respect to its root form. This peculiarity is morphologically sensitive in so far as the information that conveys is required to produce the convenient verb forms. This peculiarity, however, differs from the rest of morphological sensitive peculiarities in one important respect: that it has nothing to do with verbal classes definition. Given its individual nature, if the root form was taken into account, any verb would become the only member of an individual —and an excluding - class. As an outside peculiarity of verbal class formation, it has nothing to do with the world of rules: it is neither a predictable fact nor a formal constituent in predictions. A logical conclusion of this is that the phonological peculiarity is irrelevant to the distinction regularity vs. irregularity: it is simply not involved in any way. ${ }^{11}$

If the domain of the root is strange to the domain of rules, there seems to be no point in keeping the conventional assumption that, as far as the verbal root is

9. Cf. Perea (2002).

10. Cf. Perea (2002).

11. Cf. Viaplana (1996). 
concerned, verbs with only one phonological root are regular verbs whereas verbs with more than one root are irregular verbs. It is certainly true that it is typical for verbs to have just one phonological root, which naturally means that is atypical for a verb to have more than one root. Under the concept of rule previously adopted, however, atypical must not be confused with irregular. However both concepts have to do with statistical infractions, they are of different nature and therefore should not be confused.

On these assumptions, thus, there is no clear reason to consider that velar verbs are irregular verbs because of the plurality of their roots. This characteristic, certainly, allows them to be considered as atypical verbs, but by no means as irregular verbs.

1.2.4. The remaining fact in which velar verbs depart from verbs such as perdre is related to the person-number affix when referring to the grammatical features «indicative», «present», «first person singular».

This fact could certainly be viewed as the effect of a negative peculiarity - that is to say, as the result of a peculiarity whose presence in the lexical entry would block the application of the morphological rule predicting the affix $/ \mathrm{u} / \mathrm{in}$ the aforementioned context. The inclusion of a peculiarity of this sort in the lexicon entries of velar verbs would produce the wanted result - that is, verb forms deprived of the mode-tense affix / $\mathrm{u} /$ were expected. But it would necessarily convert the class of velar verbs into a marginal class - as it would contain as a defining peculiarity an exceptional one-, and therefore would include velar verbs in the list of irregular verbs.

Assuming that velar verbs are regular verbs, the same fact can also be viewed as a morphological characteristic of velar verbs. If the class of velar verbs is considered as a general class, the rules producing the forms of velar verbs are also to be considered as regular rules. In this context, and as far as the ending is concerned, verbs such as beure would just differ from verbs such as perdre in the sense that in the production of the former no rule is provided to assign a mode-tense affix as an exponent of the previously mentioned grammatical features. This would involve no irregularity: just a slightly different behavior between these two general verbal classes.

1.3. As a conclusion of what it has been said so far, and as far as standard Catalan is concerned, velar verbs seem to be better treated as general verbs than as marginal verbs, and therefore as regular verbs than as irregular verbs. ${ }^{12}$

Velar verbs share with verbs such as perdre all peculiarities except for the velar segment, the absence of the «mode-tense» affix /u/ and the plurality of roots - the first two peculiarities being predictable from the feature «velar» and the last one just being an «atypicality». This being the case, it seems sensible to include the general verbal class of verbs such a perdre and the general class of verbs such as

12. The morphological character of the velar segment has also been assumed in Clua (1998), Perea (1997, 2003), Pérez Saldanya (1996) and Sifre (1991); and also, in a hesitating manner, in Pérez Saldanya et al. (2004). 
beure in one only main class, ${ }^{13}$ that of verbs of class II, of which these general classes would be subclasses. If the same were done with verbs such as sentir and servir - following in that case the grammatical convention - the resulting classification for standard Catalan verbs would follow the scheme of (6). In order to show the structural and formal parallelism between velar verbs and inchoative verbs better, the feature «inchoative» — with no descriptive justification - will be substituted by «palatal». (V = Verb.)

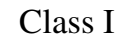

Class II

Class III

$$
\left[\begin{array}{c}
\mathrm{V} \\
\mathrm{I}
\end{array}\right]\left[\begin{array}{c}
\mathrm{V} \\
\mathrm{II} \\
\text { velar }
\end{array}\right]\left[\begin{array}{c}
\mathrm{V} \\
\mathrm{II} \\
\text { non-velar }
\end{array}\right]\left[\begin{array}{c}
\mathrm{V} \\
\mathrm{III} \\
\text { palatal }
\end{array}\right]\left[\begin{array}{c}
\mathrm{V} \\
\mathrm{III} \\
\text { non-palatal }
\end{array}\right]
$$

2.0. As far as verbal conjugation is concerned, standard Catalan follows central varieties closely. These varieties, and therefore the standard variety, differ from the rest of varieties in the forms of the inflectional affixes (cf. (7a)), in the form of palatal extensions (cf. (7 b)) and, particularly, in the presence or absence of velar segments in verbal classes other than that of class II (cf. (7c)). The first two variations are of no interest in the present work. The interest of the third one, in turn, is crucial.

(7) a. cant/u/; cant/o/, cant/i/, cant/e/, cant

b. serv/éf/o; serv/íf/o, serv/ísk/o (or serv/ísk/)

c. perdi; per/g/a, pérd/ig/a

The presence of a velar segment in verbs other than class II velar verbs is rather common in non-northern-central Catalan varieties. It is almost a general fact in western varieties, it is a frequent fact in Balearic varieties and it is a recognized regular fact in the Alguerese variety. Given the extension of this phenomenon, it seems convenient to examine its behavior in the language and also to redesign Catalan grammar so as to make it able to account for it.

2.1.0. The velar segment occurring in velar verbs is always the segment $/ \mathrm{g} /$. If it is viewed as a morphological segment, it must be supposed that in velar verbs three different roots operate; in the case of the verb beure, for example, the roots would be /bé/, /beb/ and /béw/. Roots of the type /bé/ would be selected when morphological rules happen to introduce the velar segment as an extension segment in the

13. «Main class» is used in the sense of conjugation class. It must not be confused with «general class», which refers to a set of formal elements that deserves to be treated as a class from the linguistic congruency point of view. 
structure of velar verbal forms. Nevertheless, velar verbs are atypical verbs as far as the number of roots is concerned. Typical verbs have one root only. When verbal roots happen to finish with a consonant or with a consonant cluster - sentir: sent; perdre: perd; servir: serv— the velar segment usually occurs as /ig/ —cf. senti/g/em, perdi/g/em, servi/g/em. In the case of most Valencian varieties, in which the velar segment remains strictly within class II, the general tendency consists in keeping the velar segment $/ \mathrm{g} /$ with the consequent drop of the last vowel of the root - cf. per/g/em.

When the velar segment occurs in the paradigm of verbs other than that of standard velar verbs, this segment occurs within the distributional frame in which it appears in velar verbs. In most of the cases, it covers just a part of its typical distribution. In the case of verbs such as perdre, however, verbs belonging to the II non-velar class in the standard variety, the velar segment may cover the same distribution as typical velar verbs. In this situation verbs such as perdre are to be considered as proper velar verbs - and, as a logical result, the II non-velar verbs class must be dropped from the grammar of those varieties in which this phenomenon happens.

In the Alguerese variety things are rather different in this respect, and deserve a consideration apart.

2.1.1. The northern, the southern and, in less degree, the central varieties of northwestern Catalan exhibits occurrences of a velar segment in the forms of verbs such as perdre, sentir and servir. In general terms it can be said that this segment may occur in all the morphological contexts where it occurs in velar verbs except for the one related to the grammatical features «present», «indicative», «first person singular». In fact, however, the distribution of its occurrence in these verbs varies according to the dialectal area where the varieties in question occur.

In the northern varieties of north-western Catalan the velar segment occurs in forms of verbs such as sentir and servir. The velar segment can occasionally occur in some forms of verbs such as perdre; in this case, and given their occasional character, velar forms may well be considered as simple variations of non-velar forms. In verbs such as sentir and perdre the velar segment usually occurs in all forms corresponding to «subjunctive» and to «imperative», in this last case with the exception of the form corresponding to «second person singular». In verbs such as servir, in turn, the velar segment occurs in the forms corresponding to «past», «subjunctive», and to «present», «subjunctive» and to «imperative», «first and second person plural».

\section{(8) sentir}

Pres. Subj. sént/ig/a, sént/ig/es, sénti/ig/e, sent/ig/em, sent/ig/eu, sént/ig/en Past Subj. sent/ig/essa, sent/ig/esses, sent/ig/és, sent/ig/éssem, sent/ig/ésseu, sent/ig/essen

Imp. sent, sént/ig/e, sent/ig/em, sent/ig/eu, sént/ig/en 


\section{servir}

Pres. Subj. serviska, serviskes, serviske, ${ }^{14}$ serv/ig/em, serv/ig/eu, servisken

Past Subj. serv/ig/essa, serv/ig/esses, serv/ig/és, serv/ig/éssem, serv/ig/ésseu, serv/ig/essen

Imp. servís, serviske, serv/ig/em, serv/ig/eu, servisken

perdre

Pres. Subj. pérd/ig/a, pérd/ig/es, pérd/ig/e, perd/ig/em, perd/ig/eu, pérd/ig/en

Past Subj. perd/ig/essa, perd/ig/esses, perd/ig/és, perd/ig/éssem, perd/ig/ésseu, perd/ig/essen

Imp. perd, pérd/ig/e, perd/ig/em, perd/ig/eu, pérd/ig/en

In southern varieties of north-western Catalan the velar segment occurs in forms of the verbs such as sentir, servir and perdre. In verbs such as sentir and perdre the velar segment usually occurs in the forms related to «subjunctive» and in those related to «imperative», «third person singular», and to «first, second and third person plural». In verbs such as servir, in turn, the velar segment occurs in forms related to «past», «subjunctive», to those related to «present», «subjunctive», «first and second person plural», and also to those related to «imperative», «first and second person plural».

\section{(9) sentir}

Pres. Subj. sént/ig/e, sént/ig/es, sént/ig/e, sent/ig/éssem, sent/ig/ésseu, sént/ig/en

Past Subj. sent/ig/essa, sent/ig/esses, sent/ig/és, sent/ig/éssom, sent/ig/éssou, sent/ig/essen

Imp. sent, sént/ig/e, sent/ig/em, sent/ig/eu, sént/ig/en

servir

Pres. Subj. serviska, serviskes, serviske, serv/ig/em, serv/ig/eu, servisken

Past Subj. serv/ig/essa, serv/ig/esses, serv/ig/és, serv/ig/éssom, serv/ig/éssou, serv/ig/essen

Imp. servís, serviske, serv/ig/em, serv/ig/eu, servisken

perdre

Pres. Subj. pérd/ig/a, pérd/ig/es, pérd/ig/e, perd/ig/em, perd/ig/eu, pérd/ig/en

Past Subj. perd/ig/essa, perd/ig/esses, perd/ig/és, perd/ig/éssom, perd/ig/éssou, perd/ig/essen

Imp. perd, pérd/ig/e, perd/ig/em, perd/ig/eu, pérd/ig/en

14. The segment -isc- /isk/ may be considered as an alternative representation of the palatal affix of class III verbs. 
In the central variety of north-western Catalan the diffusion of the velar segment is less frequent. In the varieties where it appears in non-velar verbs, its occurrence is usually reduced to the forms related to «past», «subjunctive» in verbs such as servir and, less often, in verbs such as sentir.

(10) servir

Past Subj. serv/ig/és, serv/ig/esses, serv/ig/és, serv/ig/éssem, serv/ig/ésseu, serv/ig/essen

\section{sentir}

Past Subj. sent/ig/és, sent/ig/esses, sent/ig/és, sent/ig/éssem, sent/ig/ésseu, sent/ig/essen

2.1.2. In most Valencian varieties the distribution of the velar segment in verbs such as perdre happens to be the same as that of verbs such as beure. ${ }^{15}$ This makes reasonable to assume that in most Valencian varieties there is just one general class of verbs belonging to class II, that it is the velar verbs class. Assuming that the velar segment occurring in verbs such as sentir and servir in the forms related to «present», «indicative», «first person singular» —cf. sen/k/and servis/k/— is not an extension segment, the occurrences of the velar segment as an extension segment is reduced, in these varieties, to the verbs of class II - that is to say, to velar verbs. ${ }^{16}$

(11) perdre

Pres. Indic. per/g/

Pres. Subj per/g/a, per/g/es, per/g/a, per/g/em, per/g/eu, per/g/en

Past Subj. per/g/era, per/g/eres, per/g/era, per/g/érem, per/g/éreu, per/g/eren Imp. perd, per/g/a, per/g/em, per/g/eu, per/g/en

2.1.3. In Balearic varieties the presence of the velar segment in non-velar verbs can be founded in the forms of verbs such as sentir and servir. In the varieties spoken in Majorca and Ibiza the velar segment usually occurs in the forms related to «present», «subjunctive», «first and second person plural», and to «imperative», «first person plural» — and, occasionally, «second person plural».

(12) sentir

Pres. Subj. senti, sentis, senti, sent/ig/em, sent/ig/eu, sentin

Imp. sent, senti, sent/ig/em, sentiu, sentin

servir

Pres. Subj. serveixi, serveixis, serveixi, serv/ig/em, serv/ig/eu, serveixin Imp. serveix, serveixi, serv/ig/em, serviu, serveixin 
In Minorcan varieties the velar segment occurs as well in the forms of verbs such as sentir and servir related to «past», «subjunctive», «first and second person plural».

\section{(13) sentir}

Past Subj. sentís, sentissis, sentís, sent/ig/éssim, sent/ig/éssiu, sentissin servir

Past Subj. servís, servissis, servís, serv/ig/éssim, serv/ig/éssiu, servissin

2.1.4. Finally, in the variety spoken in Alghero (i.e. Alguerese) a new phenomenon is found. In all Catalan non-standard varieties considered so far the velar segment occurs in velar verbs and in non-velar verbs other than those belonging to class I. On the basis of these varieties, therefore, it seems reasonable to conclude that, as far as the velar segment is concerned, in Catalan there is a borderline that keeps apart verbs belonging to class I from those belonging to the rest of classes. This borderline, however, disappears as soon as the conjugation of the Alguerese variety is taken into consideration.

The Alguerese variety, in fact, differs from the rest of Catalan varieties mainly in the fact that verbs belonging to class I are split into three different subclasses: that of the verbs such as cantar, that of the verbs such as odiar 'to hate' and that of the verbs such as canviar 'to change'. The paradigm of verbs such as cantar follows, roughly, the general one of the verbs belonging to class I. The paradigms of the other two, in turn, differ from the general one mainly in the fact that certain forms of these two verbs exhibit an extension segment. In the case of verbs such as odiar, the extension segment is of palatal nature; in the case of verbs such as canviar, in turn, the extension segment is of velar nature.

The palatal extension segment occurring in verbs such as odiar, /édz/, has exactly the same distribution as the extension segment occurring in verbs such as servir. It appears, therefore, in those forms of these verbs related to «present» — «indicative», «subjunctive» and «imperative»-, «first, second and third person singular» and «third person plural».

(14) odiar

Pres. Ind. odi/édz/, odi/édz/as, odi/édz/a, odiem, odiau, odi/édz/an

Pres. Subj. odi/édz/i, odi/édz/is, odi/édz/i, odiem, odieu, odi/édz/in Imp. odi/édz/a, odi/édz/i, odiem, odiau, odi/édz/in

The velar extension segment occurring in verbs such as canviar, /g/, occurs in those verb forms related to «present», «indicative», «first person singular»; «future»; «conditional»; «present», «subjunctive», «first, second and third person singular» and «third person plural»; and «imperative», «third person singular» and «third person plural». 
(15) canviar

Pres. Ind. canvi/k/, canvias, canvia, canviem, canviau, canvian

Fut. canvi/g/aré, canvi/g/arás, canvi/g/arà, canvi/g/arem, canvi/g/areu, canvi/g/aran

Cond. canvi/g/ariva, canvi/g/arivas, canvi/g/ariva, canvi/g/arívam, canvi/g/arívau, canvi/g/arivan

Pres. Subj. canvi/g/i, canvi/g/is, canvi/g/i, canviem, canvieu, canvi/g/in Imp. $\quad$ canvia, canvi/g/i, canviem, canviau, canvi/g/in

2.1.5. The previous data allow to see how widespread the presence of the velar segment in verb forms is in non-standard Catalan varieties. ${ }^{17}$ Not only does it occur in typical forms of velar verbs, but it often occurs in forms of non-velar verbs as well. In the vast majority of varieties in which the velar segment occurs in nonvelar verbs, its presence is reduced to verbs such as perdre, sentir and servir; that is, to all non-velar verbs except for those belonging to class I. In the case of the Alguerese variety, however, a general class of verbs belonging to the main class I also exhibits a velar segment.

All this suggests that, if those Catalan verbs showing a velar segment were considered as irregular verbs, the effect in the grammar of many Catalan varieties would be dramatic. In the case of most Valencian varieties, there would be no regular verb belonging to class II. In the case of Balearic varieties, there would be no regular verb belonging to class III. In the case of north-western varieties, as far as the central varieties are concerned, in some cases there would be no regular verb belonging to class III, palatal; in others there would be no regular verb belonging to class III, tout court; as far as the further north-western and the southern varieties are concerned, there would be no regular verb except for those belonging to class I. Finally, in the case of the Alguerese variety, there would be no regular verbs such a canviar, verbs belonging to class I as a subclass.

Obviously, conclusions like these could never be acceptable for a Catalan grammar aiming at accounting — particularly, at least — for the general facts of the language. As these conclusions follow logically from the conventional assumptions on the velar segment in Catalan verbs, it seems convenient to believe that these assumptions must be modified. The assumptions made in this work in relation to the velar segment aim at being a better alternative to them.

17. The distribution of the velar segment in verbs other than the typical velar verbs may vary considerably from one dialectal variety to another. That must be seen as a common phenomenon of dialectal morphological variation. In the context of particular dialects, where any comparative dialectal description must found its base, the distribution of the velar segment tends to be fixed - with a small range of idiosyncratic variation, if any. 
3.0. On the basis of what has been said above, the way to approach the general classification of Catalan verbs seems to be open.

A classification of this sort - typical of a general Catalan grammar - may be seen as a display showing what is general and what is particular in the several verb classifications that emerge from the different Catalan varieties. The general constituents and the particular constituents in this display are the common and the uncommon elements, respectively, in all possible Catalan verb classification.

A general classification of Catalan verbs can be expected to provide some further conclusions about the general behavior of Catalan verbs.

3.1. In order to establish a general classification of Catalan verbs, the following steps must be taken:

a. determine the features on the basis of which the general classes of Catalan verbs considered so far can be distinguished among them,

b. identify each general class of Catalan verbs in terms of these features, and

c. establish the internal organization of those features identifying the general classes of Catalan verbs, in terms of features or groups of features.

3.1.1. The categorical feature and the main-class feature left apart, the features proposed to distinguish the general classes of Catalan verbs among them will be [velar], [velarized] and [palatal], preceded by + or - . The feature [+velar] / [-velar] distinguishes velar verbs from non-velar verbs -i. e. verbs such as beure, with the whole distribution of the velar segment, from the rest of verbs. The feature [+velarized] / [-velarized] distinguishes non-velar verbs, with velar forms, from non-velar verbs without velar forms. Finally, the feature [+palatal] / [-palatal] distinguishes verbs with a palatal extension from the rest of verbs.

3.1.2. Focusing on the extension segment, and leaving aside formal realizations and distributional details, ten general classes of Catalan verbs have been detected so far. These classes can be roughly exemplified in the following terms: verbs such as cantar, verbs such as canviar in the Alguerese variety, verbs such as odiar in the Alguerese variety, verbs such as perdre in the standard variety, verbs such as perdre in some north-western varieties, verbs such as beure, verbs such as sentir in the standard variety, verbs such as sentir in certain north-western and Balearic varieties, verb such as servir in the standard variety and verbs such as servir in some north-western and in some Balearic varieties.

Assuming for economical reasons that the generic feature [velar] only concerns verbs of class II and that it systematically excludes the generic feature [velarized], and also that the general feature [palatal] does not concern class II, the definition of the general verbal classes in Catalan in terms of features can be made as follows: 
(16) a. cantar

b. canviar (Alguerese)

c. odiar (Alguerese)

d. perdre (Standard)

e. perdre (North-western)

f. beure

g. sentir (Standard)

h. $\quad$ sentir (North-western, Balearic)

i. $\quad$ servir (Standard)

j. $\quad$ servir (North-western, Balearic)
[+V, +I, -palatal, -velarized]

$[+\mathrm{V},+\mathrm{I},-$ palatal, +velarized]

[+V, +I, +palatal, -velarized]

[+V, +II, -velarized]

[+V, +II, +velarized]

$[+\mathrm{V},+\mathrm{II},+$ velar $]$

[+V, +III, -palatal, -velarized]

[+V, +III, -palatal, +velarized $]$

[+V, +III, +palatal, -velarized]

[+V, +III, +palatal, +velarized]

3.1.3. The features defining the general classes of Catalan verbs are internally organized. In fact, they can be seen as a result of a set of operations each one being triggered off by one particular feature. Some of these operations are compulsory and the others are optional. Alternative operations triggered off by the same feature lead to different results. Each operation adds new features to the set of features that defines each general class. The feature $[+\mathrm{V}]$ triggers off the alternative features $[+\mathrm{I}],[+\mathrm{II}]$ and $[+\mathrm{III}]$. The feature $[+\mathrm{I}]$ triggers off the features [-palatal, -velarized] (cf. (16a)) and may trigger off the features [+velarized] (cf. (16b)), on one side, and [+palatal] (cf. (16c)), on the other, solidarily. The feature [+II] triggers off the feature [+velar] (cf. (16f)) and may trigger off the alternative set of features [-velar, -velarized] (cf. (16d)) or the set of features [-velar, +velarized] (cf. (16e)). Finally, the feature [+III] triggers off either the alternative set of features [-palatal, -velarized] (cf. (16g)), on the one side, and [-palatal, +velarized] (cf. (16h)), on the other, or [+palatal, -velarized] (cf. (16i)), on the one side, and [+palatal, +velarized] (cf. (16j)), on the other.

3.1.4. If continuous lines represent compulsory operations, discontinuous lines represent optional operations, square brackets represent blocks of features and braces represent alternative operations, the general classification of Catalan verbs may be represented as (17): 
(17)

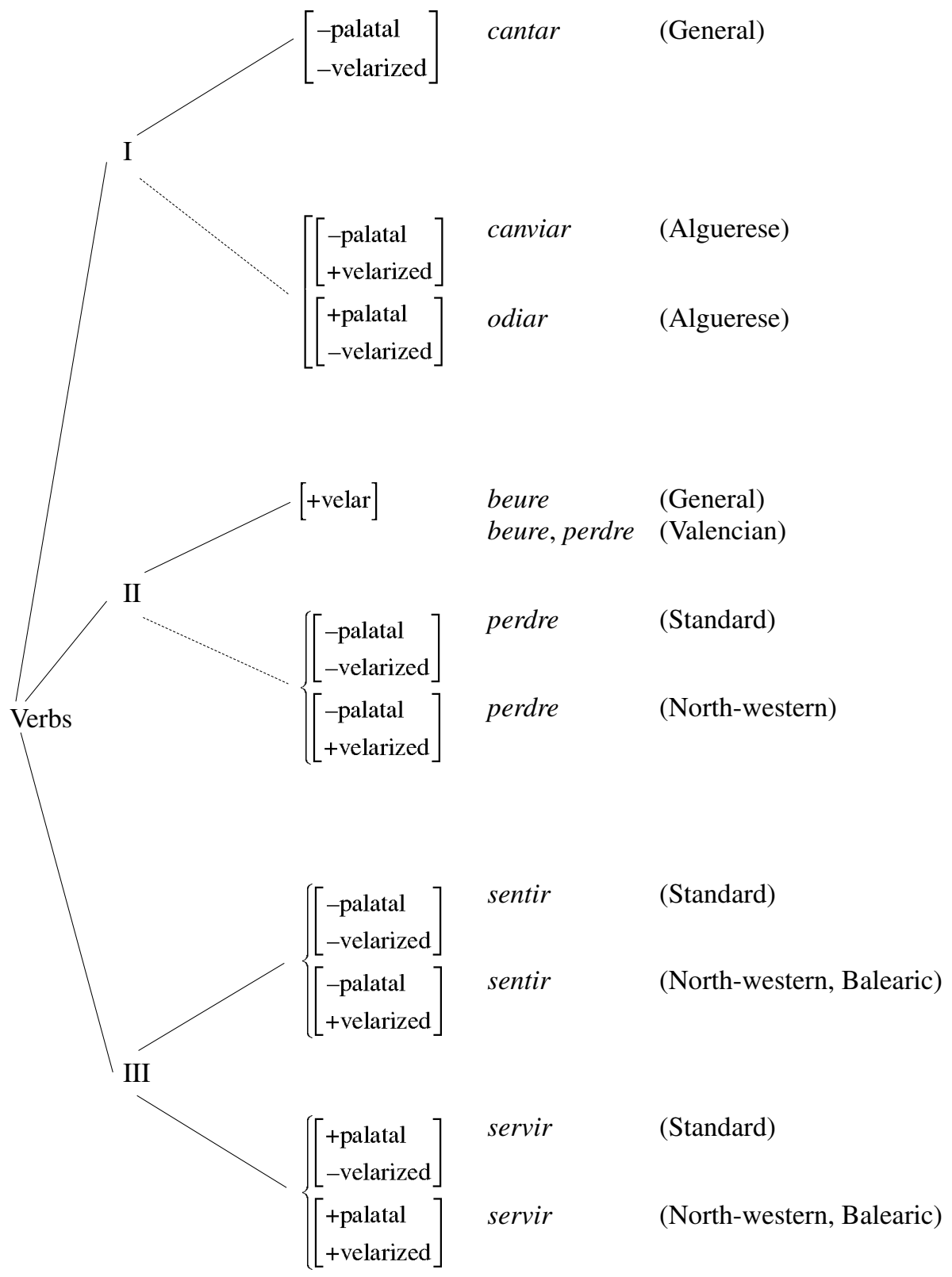


3.2. In the view of this classification, it is easy to see what is general and what is particular, what is common and what is not, in the several verb classifications that emerge from the different Catalan varieties. It is just a matter of setting apart those items connected by continuous lines - that are supposed to occur in the classification of all varieties - from those items connected by discontinuous lines - that are supposed to occur only in the classification of some varieties.

The common constituents and the uncommon constituents are the following ones, respectively:
a. $[+\mathrm{I}],[+\mathrm{II}]$ and $[+\mathrm{III}]$;
b. $[+\mathrm{I},-$ palatal, - velarized $]$
c. $[+\mathrm{II},+$ velar $]$
d. [+III, -palatal]
e. [+III, +palatal]

(19) a. [(+I), +palatal $]$

b. $[(+\mathrm{I}),+$ velar $]$

c. $[(+\mathrm{II}),-$ velar, - velarized $]$

d. $[(+\mathrm{II}),-$ velar, +velarized]

e. $[(+\mathrm{III},-$ palatal $),-$ velarized $]$

f. $[(+\mathrm{III},-$ palatal $),+$ velarized $]$

g. $[(+\mathrm{III},+$ palatal $),-$ velarized $]$

h. $[(+\mathrm{III},+$ palatal $),+$ velarized $]$

On the basis of this distinction between common and uncommon elements in several classifications of Catalan verbs, the following conclusions may be drawn:

(20) a. Verbs of all Catalan varieties can be divided in three main classes: I, II and III.

b. Verbs such as cantar are the only verbs of class I common to all Catalan varieties.

c. Verbs such as beure are the only verbs of class II common to all Catalan varieties.

d. In all Catalan varieties verbs of class III are divided in two subclasses, that of verbs such as sentir and that of verbs such as servir, differing between them in the fact that the former contain the feature [-palatal] and the latter contain the feature [+palatal]. These verbs, however, are virtu- 
al in so far they have not been assigned the features [+velar] or [-velar] required by any particular Catalan variety.

e. Leaving aside for logical reasons velar verbs, all general classes of Catalan verbs except for that of verbs such as cantar can contain the feature «velarized».

4. The first part of this paper has centered on the regularity of velar verbs in the Catalan standard variety. Conventional treatments consider these verbs as irregular verbs on the basis of the presence, in some of their forms, of an extra segment /g/ and also of their requirement of having more than one root. Arguments have been given, however, to show that neither of these reasons justifies the treatment of velar verbs as irregular verbs, and also that these verbs are better treated as regular verbs.

In the standard variety the velar segment occurs only in forms of velar verbs. In many other Catalan varieties, however, the velar segment occurs also in forms of other general classes of verbs; and in some cases in forms of all general classes of verbs, except for the general class of verbs such as cantar. In the case of the Alguerese variety, in which the main class I includes three different general classes, there is a general class, that of verbs such as canviar, in some of whose forms the velar segment also occurs. In that exceptional variety even some verbs of the main class I are affected by the presence of the velar segment in some of their forms.

Theoretical reasons aside, it would be a wrong decision for conventional grammar to keep considering velar verbs as irregular verbs on the basis of the number of roots required in their description. The unfortunate result would be to leave out of regular Catalan verbs the only verbal general class belonging to the main class II that happens to be common to all Catalan varieties. But it would be a worse decision to keep considering velar verbs as irregular verbs on the basis that some of their forms contain a velar segment. The unfortunate result in this case would be to assume that Catalan, as a language, does not have any general regular verbal class other than that of verbs such as cantar. There is no need to say that the decision would be still much worse on the basis of both reasons considered together.

\section{References}

Badia i Margarit, Antoni M. (1962). Gramática Catalana, vol. I. Madrid: Gredos. Bonet, Eulàlia; Lloret, Maria Rosa (1998). Fonologia catalana. Barcelona: Ariel.

Clua, Esteve (1998). Variació $i$ distància lingüística. Universitat de Barcelona, doctoral dissertation.

Fabra, Pompeu (1956). Gramàtica catalana. Barcelona: Teide.

Lloret, Maria-Rosa; Viaplana, Joaquim (1998). «Variació morfofonològica. Variants morfològiques». Caplletra 25: 43-62.

Marvà, Jeroni (1932). Curs pràctic de gramàtica catalana. Grau superior. Barcelona: Barcino.

Mascaró, Joan (1978). Catalan Phonology and the Phonological Cycle. Bloomington, Indiana: Indiana University Linguistics Club. 
Mascaró, Joan (1985). Morfologia. Barcelona: Enciclopèdia Catalana.

Perea, M. Pilar (1997). «Irregularitat i flexió verbal». Zeitschrift für Katalanistik. Revista d'Estudis Catalans 10: 65-79.

Perea, M. Pilar (2002). «Flexió verbal regular». In: Solà, Joan; Lloret, Maria-Rosa; Mascaró, Joan; Pérez Saldanya, Manuel (eds.). Gramàtica del català contemporani, vol. I. Barcelona: Empúries, pp. 583-646.

Perea, M. Pilar (2003). «La tendència expansiva del segment velar dels verbs de la segona conjugació en els dialectes catalans». In: Sánchez Miret, Fernando (ed.). Actas del XXIII Congreso Internacional de Lingüística y Filología Románica, Salamanca, 24-30 septiembre 2001. Tübingen: Max Niemeyer, pp. 403-417.

Pérez Saldanya, Manuel (1996). «Analogia i canvi morfològic: a propòsit de les formes verbals velaritzades». Caplletra 19: 279-305.

Pérez Saldanya, Manuel (1998). Del llatí al català. Morfosintaxi verbal històrica. València: Publicacions de la Universitat de València.

Pérez Saldanya, Manuel; Sifre Gómez, Manuel; Todolí Cervera, Júlia (2004). Morfologia Catalana. Barcelona: UOC.

Sifre i Gómez, Manuel (1991). «Un model generatiu per a la flexió verbal catalana». In: López García, Ángel; Rodríguez, Evangelina (eds.). Miscel-lània Homenatge a Enrique García Díez. València: Universitat de València, pp. 433-455.

Viaplana, Joaquim (1984). «La flexió verbal regular del valencià». In: Casanova, Emili (ed.). Miscel-lània Sanchis Guarner. Estudis en memòria del professor Manuel Sanchis Guarner: Estudis de llengua i literatura catalanes, vol. I. València: Universitat de València, pp. 391-407. [Revised version published in: Ferrando, Antoni (ed.) (1992). Miscel-lània Sanchis Guarner, vol III. València: Departament de Filologia Catalana de la Universitat de València; Barcelona: Publicacions de l'Abadia de Montserrat, pp. 381-423.]

Viaplana, Joaquim (1986). «Morfologia flexiva i flexió verbal catalana». Llengua \& Literatura 1: 385-403.

Viaplana, Joaquim (1996). «Sobre la irregularitat verbal». Caplletra 19: 333-348.

Wheeler, Max W. (1993). «Changing inflection: verb in North West Catalan». In: Mackenzie, David; Michael, Ian (eds.). Hispanic Linguistic Studies in Honour of F. W. Hodcroft. Llangrannog: Dolphin, pp. 171-206.

Wheeler, Max W. (2002). «Flexió verbal irregular i verbs defectius». In: Solà, Joan; Lloret, Maria-Rosa; Mascaró, Joan; Pérez Saldanya, Manuel (eds.). Gramàtica del català contemporani, vol. I. Barcelona: Empúries, pp. 649-729. 